Терапевтична стоматологія

УдК 616.314-089.23:611.977-519.8

DOI 10.11603/2311-9624.2018.3.9071

СР. В. Казакова, В. С. Мельник, Л. Ф. Горзов

ДВН3 «Ужгородський національний університет»

(ludmyla.norzov@uzhnu.edu.ua)

\title{
Показники дерматогліфіки як маркери для побудови математичних моделей ризику виникнення зубощелепних аномалій
}

Резюме. Дерматогліфічні обстеження широко застосовують у діагностиці багатьох уроджених і набутих захворювань. Доведено, що показники дерматогліфіки можуть бути використані як маркери полігенної системи для дослідження деяких закономірностей фенотипового прояву полігенних систем в онтогенезі. Вивчення спільних зв’язків між пальцевими відбитками і зубощелепними аномаліями може допомогти на ранньому етапі виявити осіб із генетичною схильністю.

Мета дослідження - розробити прогностичні математичні моделі можливості виникнення зубощелепних аномалій у чоловіків і жінок на основі аналізу особливостей дерматогліфічних показників.

Матеріали і методи. Проведено дерматогліфічне дослідження за методикою Н. Cummins i Ch. Midlo у 34 чоловіків та у 36 жінок із зубощелепними аномаліями віком 35-44 роки. Як контроль використано результати дерматогліфічних досліджень 43 практично здорових чоловіків і 44 жінок аналогічного віку. Результати досліджень та їх обговорення. Дискримінантні моделі за допомогою дерматогліфічних показників дозволили розділити міських жителів м. Ужгорода на здорових і хворих із зубощелепними аномаліями. Найбільший внесок у дискримінацію між здоровими і хворими чоловіками має довжина лінії ad на правій кисті, а між здоровими і хворими жінками - наявність осьового трирадіуса t. індексу Каміннса і довжини лінії сt на лівій кисті.

Висновки. Дискримінантні моделі виникнення зубощелепних аномалій, залежно від дерматогліфічних показників, є адекватними і можуть використовуватися для раннього прогнозу ризику виникнення цього захворювання.

Ключові слова: дерматогліфічні ознаки; пальцевий відбиток; маркери; зубощелепні аномалії.

\author{
(СР. В. Казакова, В. С. Мельник, Л. Ф. Горзов
}

ГВУз «Ужгородский национальный университет»

\section{Показатели дерматоглифики как маркеры для построения математических моделей риска возникновения зубочелюстных аномалий}

Резюме. Дерматоглифические обследования широко применяют в диагностике многих врожденных и приобретенных заболеваний. Доказано, что показатели дерматоглифике могут быть использованы в качестве маркеров полигенной системы для исследования некоторых закономерностей фенотипического проявления полигенных систем в онтогенезе. Изучение общих связей между пальцевыми отпечатками и зубочелюстными аномалиями может помочь в раннем выявлении лиц с генетической предрасположенностью.

Цель исследования - разработать прогностические математические модели возможности возникновения зубочелюстных аномалий у мужчин и женщин на основании анализа особенностей дерматоглифических показателей.

Материалы и методы. Проведено дерматоглифических исследования по методике H. Cummins и Ch. Midlo в 34 мужчин и в 36 женщин с зубочелюстными аномалиями в возрасте 35-44 лет. В качестве контроля использованы результаты дерматоглифических исследований 43 практически здоровых мужчин и 44 женщин аналогичного возраста.

Результаты исследований и их обсуждение. Дискриминантные модели с помощью дерматоглифических показателей позволили разделить городских жителей г. Ужгорода на здоровых и больных с зубочелюстными аномалиями. Наибольший вклад в дискриминацию между здоровыми и больными мужчинами имеет протяженность линии ad на правой кисти, а между здоровыми и больными женщинами - наличие осевого трирадиуса t’, индекса Каминнса и длины линии сt на левой кисти. 
Выводы. Дискриминантные модели возникновения зубочелюстных аномалий в зависимости от дерматоглифических показателей являются адекватными и могут использоваться для раннего прогноза риска возникновения этого заболевания.

ключевые слова: дерматоглифические признаки; пальцевые отпечатки; маркеры; зубочелюстные аномалии.

\section{COR. V. Kazakova, V. S. Melnyk, L. F. Horzov}

Uzhhorod National University

\section{Indicators of dermatoglyphics as markers for the construction of mathematical models for the risk of dentognathic anomalies}

Summary. Dermatological examinations are widely used in the diagnosis of many congenital and acquired diseases. It is proved that indicators of dermatoglyphics can be used as markers of a polygenic system for the study of some patterns of phenotypic manifestation of polygenic systems in ontogenesis. Investigating the relationship between finger drawings and dentognathic anomalies can help in the early detection of individuals with genetic predisposition.

The aim of the study - to develop prognostic mathematical models of the possibility of dentognathic anomalies in men and women based on the analysis of the features of dermatological characteristics.

Materials and Methods. Dermatoglyphic study was performed using H. Cummins and Ch. Midlo in 34 men and 36 women with dentognathic anomalies aged 35-44 years. As a control, the results of dermatological studies 43 healthy men and 44 women of the same age were used.

Results and Discussion. Discriminant models with the help of dermatological indicators allow the city residents of Uzhhorod to be divided into healthy and sick with dentognathic anomalies. The greatest contribution to discrimination between healthy and sick men is the length of the line ad on the right hand, and between healthy and sick women, the presence of the axial triadius t ', the Kamins index and the length of the line ct on the left hand.

Conclusions. Discriminant models of dentognathic anomalies, depending on dermatoglyphic parameters, are adequate and can be used for early prediction of the risk of developing this disease.

Key words: dermatological signs; skin figure; markers; dentognathic anomalies.

Вступ. Порушення в розвитку зубощелепного апарату завдають шкоди не тільки здоров’ю дитини, але і негативно впливають на іï адаптацію в соціальному середовищі. За даними багатьох досліджень, поширеність зубощелепних аномалій (ЗЩА) в структурі стоматологічної захворюваності стоїть на третьому місці після карієсу зубів і патології тканин пародонта [5-7, 9].

У дослідженнях останніх років відзначають збільшення розповсюдження зубощелепних аномалій (П. С. Фліс (2015)), а показники їх частоти у дітей різних регіонів України свідчать про поліетіологічний фактор появи даної патології [11].

Серед причин виникнення зубощелепних аномалій виділяють: спадковість (17,8 \%), ендогенний фактор і шкідливі звички (17,8 \%), екзогенний фактор, карієс і раннє видалення зубів (15,0 \%), неправильне штучне вигодовування (14,0 \%), порушення термінів прорізування і зміни зубів (13,2 \%), несприятли- вий перебіг вагітності (12,8 \%), ЛОР-патології $(9,4 \%)$ [10].

Велике значення в розвитку зубощелепних аномалій має спадковість. За нею передаються аномалії розміру, форми, структури зубів, розміру щелеп, уроджених незрощень у щелепно-лицевій ділянці, на що звернули увагу П. С. Фліс, В. Д. Куроєдова, Б. М. Мирчук, С. I. Дорошенко (2009), Ф. Я. Хорошилкіна (2012), Б. Eis-mann (2010), R. Frankel (2013), H. G. Gerlach (2014) та ін.

Вивчення спільних зв’язків між пальцевими відбитками і ЗЩА може допомогти на ранньому етапі виявити осіб із генетичною схильністю до ЗЩА. Із використанням сучасних методів реєстрації цей процес значно спрощений. Генетична зумовленість шкірних узорів, індивідуальність їх варіацій та незмінність протягом життя дозволяє віднести їх до прогностичних ознак [2, 4].

Для розшифрування механізмів схильності до ЗЩА, потрібно вивчити вплив конкрет- 
них генетичних чинників (маркерів). Це дало б змогу оцінити індивідуальну схильність до ЗЩА, щоб серед родичів хворих першого ступеня споріднення відібрати для диспансерного спостереження осіб із найбільшим ризиком розвитку захворювання та спробувати, вплинувши на відомі несприятливі чинники розвитку або погіршення перебігу ЗЩА, запобігти вияву патологічних генів.

Дерматогліфічні обстеження широко застосовують у діагностиці багатьох уроджених i набутих захворювань [1-4]. Доведено, що показники дерматогліфіки можуть бути використані як маркери полігенної системи для дослідження деяких закономірностей фенотипового прояву полігенних систем в онтогенезі [8].

Метою дослідження було розробити прогностичні математичні моделі можливості виникнення ЗЩА в чоловіків і жінок на основі аналізу особливостей дерматогліфічних показників.

Матеріали і методи. Проведено дерматогліфічне дослідження за методикою H. Cummins i Ch. Midlo [12] у 34 чоловіків та у 36 жінок із ЗЩА віком 35-44 роки. Як контроль використано результати дерматогліфічних досліджень 43 практично здорових чоловіків і 44 жінок аналогічного віку. В дослідження було включено чоловіків та жінок української національності, мешканців м. Ужгорода, у зв'язку з тим, що дерматогліфічним ознакам притаманні національні та статеві розбіжності (И. Гусева, 1986) [12].

Для побудови прогностичних математичних моделей з урахуванням дерматогліфічних показників використано метод покрокового дискримінантного аналізу, який за допомогою змінних величин дозволяе класифікувати спостереження за групами. Статистичну обробку результатів проведено за допомогою пакета Statistica 5.5.

Результати досліджень та їх обговорення. Встановлено, що в разі врахування показників пальцевої і долонної дерматогліфіки дискримінантна функція охоплює 77,0 \% здорових чоловіків та 68,2 \% із ЗЩА. Взагалі модель, у якій взято до уваги дані пальцевої і долонної дерматогліфіки, коректна в 65,7 \% випадків (рис.).

Між здоровими та чоловіками з ЗЩА дискримінантними змінними є осьовий трирадіус t' на лівій і правій кистях, гребінцевий візерунок лінії ab на правій і лівій кистях, довжина лінії ad на правій кисті, гребінцевий візерунок лінії bc на правій кисті, величина

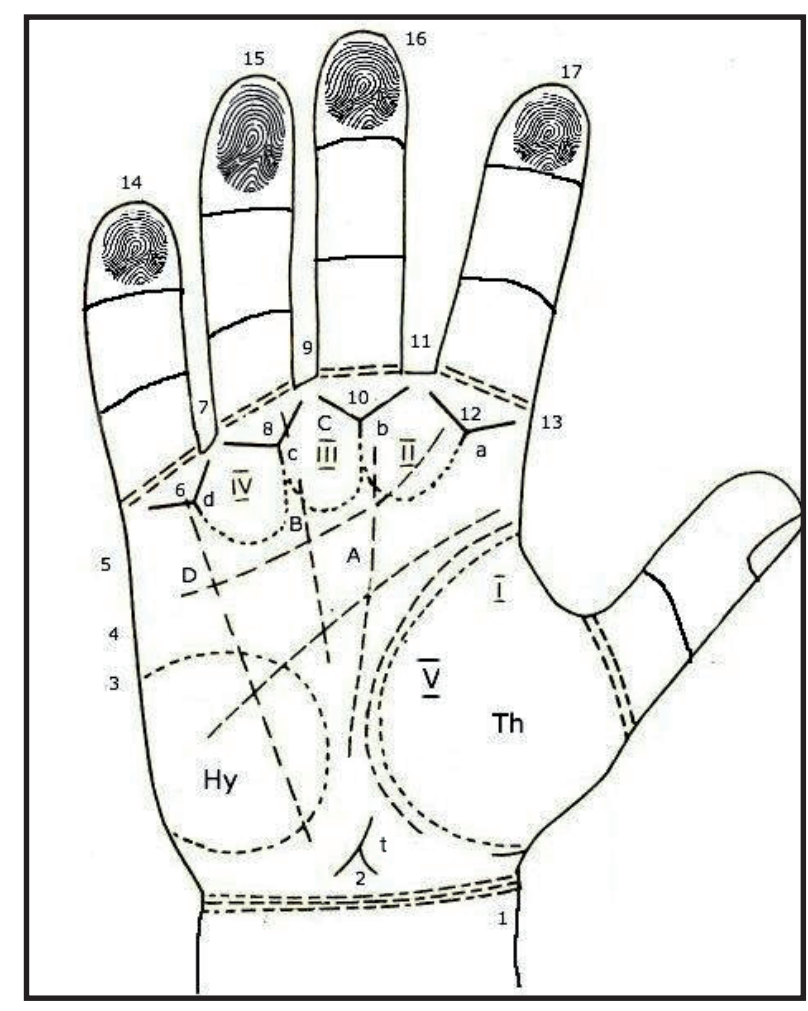

Рис. Папілярні утворення на долоні.

Примітка. 1-13 - долонні поля; Ну - гіпотенар; Th тенар; I, II, III, IV - міжпальцеві поля; V - згинальні борозни долоні; a, b, c, d - міжпальцеві трирадіуси; А, B, C, D - головні долонні лінії; $\mathrm{t}$ - осьовий долонний трирадіус; 14-17 - основні пальцеві відбитки (14 ульнарна петля, 15 - завиток, 16 - дуга, 17 - радіальна петля).

кута dat на лівій кисті та осьовий трирадіус t” на правій кисті.

Причому найбільше значення у дискримінації між здоровими та чоловіками з ЗЩА має довжина лінії ad на правій кисті. Всі інші дискримінантні змінні роблять незначний, але достовірний поодинокий внесок у дискримінацію між сукупностями. Сукупність усіх змінних має середньозначущу (статистика Wilks' Lambda: 0,563; F=6,81; $\mathrm{p}<0,0001)$ дискримінацію між здоровими і чоловіками із ЗЩА (табл. 1). Оскільки F критичне $(16,32)$, майже втричі більше від F розрахункового (6,81), однозначно стверджувати про повну коректність функціонування моделі ми не можемо.

Параметри класифікаційної функції між здоровими та чоловіками із ЗЩА, залежно від особливостей показників пальцевої і долонної дерматогліфіки, наведено в таблиці 2.

Показник класифікації Df (для здорових чо ловіків $)=A \times 20,27+B \times 1,268+C \times 3,726-D \times 0,209+E \times$ $4,125+F \times 405,5=\mathrm{G} \times 1,334=\mathrm{H} \times 20,19=631,7$, де (тут $\mathrm{i}$ в подальшому) наявність осьового трирадіуса: 
таблиия 1. Дискримінантний аналіз здорових та чоловіків із зубощелепними аномаліями залежно від показників пальцевої і долонної дерматогліфік

\begin{tabular}{|l|c|c|c|c|}
\hline \multicolumn{1}{|c|}{ Дискримінантна змінна } & $\begin{array}{c}\text { Wilks’ } \\
\text { Lambda }\end{array}$ & $\begin{array}{c}\text { Partial } \\
\text { Lambda }\end{array}$ & $\begin{array}{c}\text { FEremove } \\
(2,17)\end{array}$ & PElevel \\
\hline Наявність осьового трирадіуса t’ на лівій кисті & 0,630 & 0,878 & 10,50 & 0,0001 \\
\hline Гребінцевий візерунок лінії аb на правій кисті & 0,617 & 0,902 & 8,661 & 0,0003 \\
\hline Довжина лінії ad на правій кисті & 0,680 & 0,813 & 18,01 & 0,0001 \\
\hline Гребінцевий візерунок лінії ьс на правій кисті & 0,611 & 0,905 & 7,754 & 0,0006 \\
\hline Величина кута dat на лівій кисті & 0,601 & 0,935 & 4,871 & 0,0087 \\
\hline Наявність осьового трирадіуса t” на правій кисті & 0,605 & 0,929 & 5,433 & 0,0051 \\
\hline Гребінцевий візерунок лінії аb на лівій кисті & 0,584 & 0,946 & 3,821 & 0,0236 \\
\hline Наявність осьового трирадіуса t’ на правій кисті & 0,583 & 0,947 & 3,653 & 0,0268 \\
\hline
\end{tabular}

Примітка. Wilks’ Lambda: 0,563; F (16,32) = 6,81; p<0,0001.

Таблищя 2. Класифікаційні дискримінантні функції для здорових та чоловіків із зубощелепними аномаліями залежно від показників пальцевої та долонної дерматогліфік

\begin{tabular}{|c|l|c|c|}
\hline \multicolumn{1}{|c|}{ Дискримінантна змінна } & 3дорові & 3щА \\
\hline A & Наявність осьового трирадіуса t’ на лівій кисті & 20,27 & 18,54 \\
\hline В & Гребінцевий візерунок лінії аb на правій кисті & 1,268 & 3,123 \\
\hline C & Довжина лінії ad на правій кисті & 3,726 & $-0,103$ \\
\hline D & Гребінцевий візерунок лінії bс на правій кисті & $-0,209$ & 3,944 \\
\hline E & Величина кута dat на лівій кисті & 4,125 & 394,9 \\
\hline F & Наявність осьового трирадіуса t” на правій кисті & 405,5 & $-1,148$ \\
\hline G & Гребінцевий візерунок лінії аb на лівій кисті & $-1,334$ & $-18,18$ \\
\hline H & Наявність осьового трирадіуса t’ на правій кисті & $-20,19$ & $-591,1$ \\
\hline I & Константа & $-631,7$ & \\
\hline
\end{tabular}

1 - наявність ознаки, 2 - відсутність ознаки; гребінцевий візерунок - в абсолютних одиницях; довжина ліній - у міліметрах; величина кутів - у градусах.

Показник класифікації Df (для чоловіків i3 ЗЩА $=A \times 18,54+B \times 1,123+C \times 3,461-D \times-0,103+E \times$ $3,944+\mathrm{F} \times 394,9=\mathrm{G} \times 1,148=\mathrm{H} \times 18,18=591,1$.

Під час визначення значущості усіх дискримінантних функцій за допомогою критерію $\chi 2$ як між здоровими чоловіками із ЗЩА виявлено вірогідні відмінності щодо показників класифікації з урахуванням показників пальцевої і долонної дерматогліфіки (табл. 3).

3 урахуванням показників пальцевої і долонної дерматогліфік дискримінантна функція охоплює 93,3 \% здорових жінок та 43,2 \% жінок із ЗЩА. Загалом, модель, у якій взято до уваги показники пальцевої і долонної дерматогліфік, коректна у 74,2 \% випадків.

Між практично здоровими та жінками із ЗЩА дискримінантними змінними є осьовий трирадіус t’ на лівій кисті, індекс Каммінса на

Таблиия 3. Покроковий аналіз із включенням для всіх канонічних коренів у чоловіків з урахуванням особливостей показників пальцевої і долонної дерматогліфік

\begin{tabular}{|c|c|c|c|c|c|c|}
\hline & Eigenvalue & Canonicl R & $\begin{array}{c}\text { Wilks' } \\
\text { Lambda }\end{array}$ & Chi-Sqr. & df & PElevel \\
\hline 2 & 0,400 & 0,533 & 0,563 & 96,84 & 16 & 0,0001 \\
\hline 1 & 0,256 & 0,452 & 0,796 & 39,14 & 7 & 0,0001 \\
\hline
\end{tabular}


лівій кисті, пальцевий гребінцевий візерунок на п’ятому пальці лівої кисті, гребінцевий візерунок лінії bс на лівій кисті, тип візерунка на другому пальці лівої кисті, довжина лінії ct на лівій кисті, гребінцевий візерунок лінії ab на лівій кисті та величина кута atb на лівій кисті (табл. 4). Найбільший внесок у дискримінацію між здоровими та жінками із ЗЩА зробили осьовий трирадіус t' на лівій кисті, індекс Каммінса на лівій кисті та довжина лінії сt на лівій кисті. Усі інші дискримінантні змінні роблять незначний, але достовірний поодинокий внесок у дискримінацію між сукупностями.

Сукупність усіх змінних має середньозначущу (статистика Wilk's Lambda = 0,442; F=6,21; p<0,001) дискримінацію між здоровими і жінками і ЗЩА (табл. 4), оскільки F_критичне $(16,18)$ майже втричі більше від F_розрахункового $(6,21)$, од- нозначно стверджувати про повну коректність функціонування моделі ми не можемо.

Параметри класифікаційної функції між здоровими та жінками із ЗЩА залежно від показників пальцевої і долонної дерматогліфік, наведено в таблиці 5.

Показники класифікації (Df) для різних груп жінок, залежно від показників пальцевої і долонної дерматогліфік, розраховують за формулами:

Df (для здорових жінок) $=\mathrm{A} \times 12,14+\mathrm{b} \times 3,002=\mathrm{c}$ $\times 0,012+d \times 1,314+\mathrm{e} \times 0,754+\mathrm{f} \times 2,171-\mathrm{g} \times 0,876+\mathrm{h} \times$ 6,274=155,2, де (тут і в подальшому) індекс Каммінса - в абсолютних одиницях; тип візерунка на пальцях кисті: 1 - завиток, 2,1 - ульнарна петля, 2,2 - радіальна петля, 3 - дуга, 4,1 - центральна кишеня, 4,2 - латеральна кишенькова петля, 4,3 - подвоєна петля, 4,4 - випадковий візерунок.

таблищя 4. Дискримінантний аналіз здорових та жінок із зубощелепними аномаліями ЗЩА залежно від показників пальцевої і долонної дерматогліфіки.

\begin{tabular}{|l|c|c|c|c|}
\hline \multicolumn{1}{|c|}{ Дискримінантна змінна } & $\begin{array}{c}\text { Wilks' } \\
\text { Lambda }\end{array}$ & $\begin{array}{c}\text { Partial } \\
\text { Lambda }\end{array}$ & $\begin{array}{c}\text { FEremove } \\
(2,1)\end{array}$ & pElevel \\
\hline Наявність вісьового трирадіуса t’ на лівій кисті & 0,572 & 0,774 & 14,51 & 0,0001 \\
\hline Індекс Каммінса на лівій кисті & 0,548 & 0,807 & 11,72 & 0,0001 \\
\hline $\begin{array}{l}\text { Пальцевий гребінцевий візерунок п’ятого пальця } \\
\text { лівої кисті }\end{array}$ & 0,495 & 0,893 & 5,821 & 0,0040 \\
\hline Гребінцевий візерунок лінії ьс лівої кисті & 0,472 & 0,935 & 3,378 & 0,0378 \\
\hline Тип візерунка на другому пальці лівої кисті & 0,471 & 0,938 & 3,162 & 0,0462 \\
\hline Довжина лінії ст лівої кисті & 0,540 & 0,818 & 10,85 & 0,0001 \\
\hline Гребінцевий візерунок лінії аь лівої кисті & 0,523 & 0,842 & 9,123 & 0,0002 \\
\hline Величина кута ать на лівій кисті & 0,484 & 0,906 & 4,940 & 0,0090 \\
\hline
\end{tabular}

Примітка. Wilks’ Lambda: 0,442; F $(16,18)=6,21 ; \mathrm{p}<0,0001$

Таблищя 5. Класифікаційні дискримінантні функції для здорових та жінок із зубощелепними аномаліями залежно від показників пальцевої і долонної дерматогліфік

\begin{tabular}{|c|l|c|c|}
\hline \multicolumn{2}{|c|}{ Дискримінантна змінна } & 3дорові & 3ЩА \\
\hline a & Наявність осьового трирадіуса t’ на лівій кисті & 12,14 & 7,033 \\
\hline b & Індекс Каммінса на лівій кисті & 3,002 & 4,356 \\
\hline с & Пальцевий гребінцевий візерунок на п’ятому пальці лівої кисті & $-0,012$ & 0,391 \\
\hline d & Гребінцевий візерунок лінії bс на лівій кисті & 1,314 & 1,588 \\
\hline e & Тип візерунка на другому пальці лівої кисті & 0,754 & $-0,748$ \\
\hline f & Довжина лінії сt на лівій кисті & 2,171 & 2,112 \\
\hline g & Гребінцевий візерунок лінії ар на лівій кисті & $-0,876$ & $-0,762$ \\
\hline h & Величина кута ать на лівій кисті & 6,274 & 5,935 \\
\hline i & Константа & $-155,2$ & $-170,1$ \\
\hline
\end{tabular}


Df (для жінок із ЗЩА $)=\mathrm{A} \times 7,033+\mathrm{b} \times 4,356+\mathrm{c} \times$ $0,391+\mathrm{d} \times 1,588-\mathrm{e} \times 0,748+\mathrm{f} \times 2,112-\mathrm{g} \times 0,762+\mathrm{h} \times 5,935=$ 170,1

Під час визначення значущості усіх дискримінантних функцій за допомогою критерію $\chi 2$ встановлено, що можлива вірогідна інтерпретація отриманих показників класифікації як між здоровими, так і жінками із ЗЩА з урахуванням показників пальцевої і долонної дерматогліфік (табл. 6).

таблищя 6. Покроковий аналіз із включенням усіх канонічних коренів у жінок з урахуванням особливостей показників пальцевої і долонної дерматогліфік

\begin{tabular}{|c|c|c|c|c|c|c|}
\hline & Eigenvalue & Canonicl R & $\begin{array}{c}\text { Wilks' } \\
\text { Lambda }\end{array}$ & Chi-Sqr. & df & PElevel \\
\hline 2 & 0,910 & 0,688 & 0,442 & 83,72 & 16 & 0,0000 \\
\hline 1 & 0,172 & 0,383 & 0,848 & 16,67 & 7 & 0,0195 \\
\hline
\end{tabular}

3 метою практичної перевірки функціонування розроблених моделей ризику виникнення ЗЩА додатково обстежено 34 чоловіків та 36 жінок із ЗЩА, яким провели дерматогліфічне дослідження. Усіх їх порівняли за віком та місцем проживання щодо основної групи.

Використовуючи дискримінантні моделі виникнення ЗЩА, що були розроблені на основі показників дерматогліфіки, із 34 чоловіків з ЗЩА до групи з високим ризиком за-

\section{Список літератури}

1. Богданов Н. Н. Есть такая наука - дерматоглифика Н. Н. Богданов // Наука и жизнь. - 1998. - № 10. C. 43-45.

2. Волоцкой М. В. К вопросу о генетике папиллярных узоров пальцев / М. В. Волоцкой // Труды медико-генетич. ин-та им. Горького.- 1936. - Т. 4. - С. 404-439. 3. Гладкова Т. Д. Кожные узоры кисти и стопы обезьян и человека / Т. Д. Гладкова. - М. : Наука, 1966. $-151 \mathrm{c}$.

4. Гусева И. С. Морфогенез и генетика гребешковой кожи человека / И. С. Гусева. - Минск : Беларусь, 1986. - 160 c.

5. Костенко Є. Я. Поширеність та структура зубощелепних аномалій у дітей Закарпатської області / Є. Я. Костенко, В. С. Мельник // Науковий вісник Ужгородського університету. - 2016. - Вип. 1. (53) С. 102-105.

6. Куроєдова В. Д. Сучасні методи профілактики зубощелепних аномалій і деформацій / В. Д. Куроєдова, М. І. Дмитренко // Світ ортодонтії. - К., 2003. № 1(4). - С. 6-9.

7. Лучинський М. А. Частота зубощелепних аномалій та деформацій у дітей різних адаптивних типів

\section{References}

1. Bogdanov, N.N. (1998). Est takaya nauka - dermatoglifika [There is such a science dermatoglyphics]. Nauka i zhizn - Science and Life, 10, 43-45 [in Russian].

2. Volotskoy, M.V. (1936). K voprosu o genetike papillyarnykh uzorov paltsev [On the genetics of хворювання потрапило 18, що становить 52,9 \%; із них (діагноз підтвердився у 7 (63,6 \%)). Відповідно із 36 жінок до групи з високим ризиком розвитку захворювання потрапило 23, що становить 63,8 \%; із них (діагноз підтвердився у 7 (58,3 \%)).

Висновки. Дискримінантні моделі виникнення зубощелепних аномалій залежно від дерматогліфічних показників є адекватними і можуть використовуватися для раннього прогнозу ризику виникнення цього захворювання.

Прикарпаття / М. А. Лучинський // Вісник соціальної гігієни та організації охорони здоров'я України. - 2013. - № 1. - С. 31-34.

8. Методы дерматоглифики в идентификации личности погибших / под ред. А. П. Божченко, В. А. Ракитина, А. И. Самарина, В. В. Щербакова. - Ростов-наДону : Рост. издат., 2002. - С. 68-80.

9. Міськів А. Л. Структура зубощелепних аномалій у дітей Львівської області / А. Л. Міськів, Е. В. Безвушко // Acta medica Leopoliensia. - 2015. - Vol. 21, No. 2. - P. 10-13.

10. Персин Л. С. Ортодонтия. Современные методы диагностики зубочелюстно-лицевых аномаилий : руководство для врачей. - М. : ООО «ИЗПЦ «Информкнига», 2007. - 248 с.

11. Ортодонтія. Зубощелепні аномалії та деформації $=$ Dentognathic Anomalies and Deformation / П. С. Фліс, Г. П. Леоненко, В. В. Філоненко, Н. М. Дорошенко. К. : Медицина, 2015. - 176 с.

12. Cummins H. Finger prints, palms and soles. An introduction to dermatoglyphics / H. Cummins, Ch. Midlo. - Philadelphia, 1961. - 300 p.

papillary finger patterns]. Trudy mediko-genetich. in-ta im. Gorkogo - Materials of Medical Genetic Institute by Gorky, 4, 404-439 [in Russian].

3. Gladkova, T.D. (1966). Kozhnyye uzory kisti i stopy obezyan i cheloveka [Skin patterns of the hand and foot of monkeys and humans]. Moscow: Nauka [in Russian].

ISSN 2311-9624. Клінічна стоматологія. 2018. № 3 
4. Guseva, I.S. (1986). Morfogenez i genetika grebeshkovoy kozhi cheloveka [Morphogenesis and genetics of crested human skin]. Minsk: Belarus [in Russian].

5. Kostenko, Ye.Ia. \& Melnyk, V.S. (2016). Poshyrenist ta struktura zuboshchelepnykh anomalii u ditei Zakarpatskoi oblasti [Prevalence and structure of dentognathic anomalies in children of the Transcarpathian region]. Naukovyi visnyk Uzhhorodskoho universytetu - Scientific Journal of Uzhhorod University, 1 (53), 102-105 [in Ukrainian].

6. Kuroiedova, V.D., \& Dmytrenko, M.I. (2003). Suchasni metody profilaktyky zuboshchelepnykh anomalii i deformatsii [Modern methods of prophylaxis of dentognathic anomalies and deformations]. Svit ortodontii. Visnyk stomatolohii - The World of Orthodontics. Bulletin of Dentistry, 1 (4), 6-9 [in Ukrainian]. 7. Luchynskyi, M.A. (2013). Chastota zuboshchelepnykh anomalii ta deformatsii u ditei riznykh adaptyvnykh typiv Prykarpattia [Frequency of dentognathic anomalies and deformations in children of different adaptive types of Precarpathia] Visnyk sotsialnoi hihiieny ta orhanizatsii okhorony zdorovia Ukrainy - Bulletin of Social Hygiene and Health Protection Organizations of Ukraine, 1, 31-34 [in Ukrainian].
8. Bozhchenko, A.P., Rakitina, V.A., Samarina, A.I. \& Shcherbakova, V.V. (Eds.) (2002). Metody dermatoglifiki $v$ identifikatsii lichnosti pogibshikh [Methods of dermatoglyphics in identifying the identity of the deceased]. Rostov na-Donu: Rost. Izdat. [in Russian].

9. Miskiv, A.L. \& Bezvushko, E.V. (2015). Struktura zuboshchelepnykh anomalii u ditei Lvivskoi oblasti [The structure of dentognathic anomalies in children of Lviv region]. Acta medica Leopoliensia, 21, 2, 10-13 [in Ukrainian].

10. Persin, L.S. (2007). Ortodontiya. Sovremennyye metody diagnostiki zubochelyustno-litsevykh anomaliy. Rukovodstvo dlya vrachey [Orthodontics. Modern methods of diagnosis of dentofacial-facial anomalies. A guide for doctors]. Moscow: Informkniga [in Russian].

11. Flis, P.S., Leonenko, H.P. Filonenko \& V.V. Doroshenko, N.M. (2015). Ortodontiia. Zubo-shchelepni anomalii ta deformatsii [Dentognathic Anomalies and Deformation]. Kyiv: Medytsyna.

12. Cummins, H. \& Midlo, Ch. (1961). Finger prints, palms and soles. An introduction to dermatoglyphics. Philadelphia.

Отримано 03.07.18 